\title{
Notes on the status of Kuhl's Lorikeet Vini kuhlii in the Northern Line Islands, Kiribati
}

\author{
DICK WATLING
}

\begin{abstract}
Summary
Kuhl's Lorikeet Vini kuhlii has a precarious status reflected by its disjunct distribution in the Pacific, with surviving populations in the Northern Line (Kiribati) and Austral Islands (French Polynesia) some 3,00o km apart, possibly as a result of Polynesian trade in red feathers. The species is extinct in the southern Cook Islands. On Rimatara (Austral Islands), where it is believed indigenous, it is still common but the recent introduction of the Rattus norvegicus is of concern. In the Northern Line Islands, $R$. rattus appears to have all but extirpated the lorikeet on Tabuaeran (Fanning Island), but one small population has apparently survived for over 70 years, an explanation for which may guide in situ conservation of Vini lorikeets on ship-rat-infested islands elsewhere. The arid and unpredictable climate of Kiritimati (Christmas Island) may preclude the establishment of lorikeets. Only on Teraina (Washington Island), where over 1,000 V. kuhlii survive, are there no confirmed threats and good in situ conservation potential.
\end{abstract}

\section{Kuhl's Lorikeet: distribution, habitat and threats}

Kuhl's Lorikeet Vini kuhlii, considered Endangered by Collar et al. (1994), is believed to be indigenous to the French Polynesian island of Rimatara and perhaps Tubuai, although Forshaw (1989) considers that lorikeets on this island may be escaped pets. Fossil remnants of a Vini on the southern Cook Islands of Mangaia, Atiu and Aitutaki are also referable to this species (Steadman 1985, 1991) and formerly it may have been found on all the southern Cook Islands.

Kuhl's Lorikeets have also been found on all three of Kiribati's Northern Line Islands - Kiritimati (Christmas Island), Tabuaeran (Fanning Island) and Teraina (Washington Island) (Figure 1). Introductions to Kiritimati have been recent, but the lorikeet was present on Tabuaeran when it was first visited by a European, Captain Edmund Fanning, in 1798 (Fanning 1989). Its introduction to Teraina and Tabuaeran is believed to have been by early Polynesian voyagers as described by Forshaw (1989): "When Thomas Streets visited Washington, in the Line Group, with a United States survey expedition in 1874 , he met a party of natives who had come from islands to the south to harvest coconuts. They had with them a number of Kuhl's Lories as pets. In this way the species probably was introduced to both Washington and Fanning . . . some time prior to $1798^{\prime \prime}$.

Prior to the advent of Europeans in the Pacific, there was a well-established trade in red feathers amongst Pacific islanders, and the predominantly red plumage of Kuhl's Lorikeet would have made it a prize candidate for trade. 


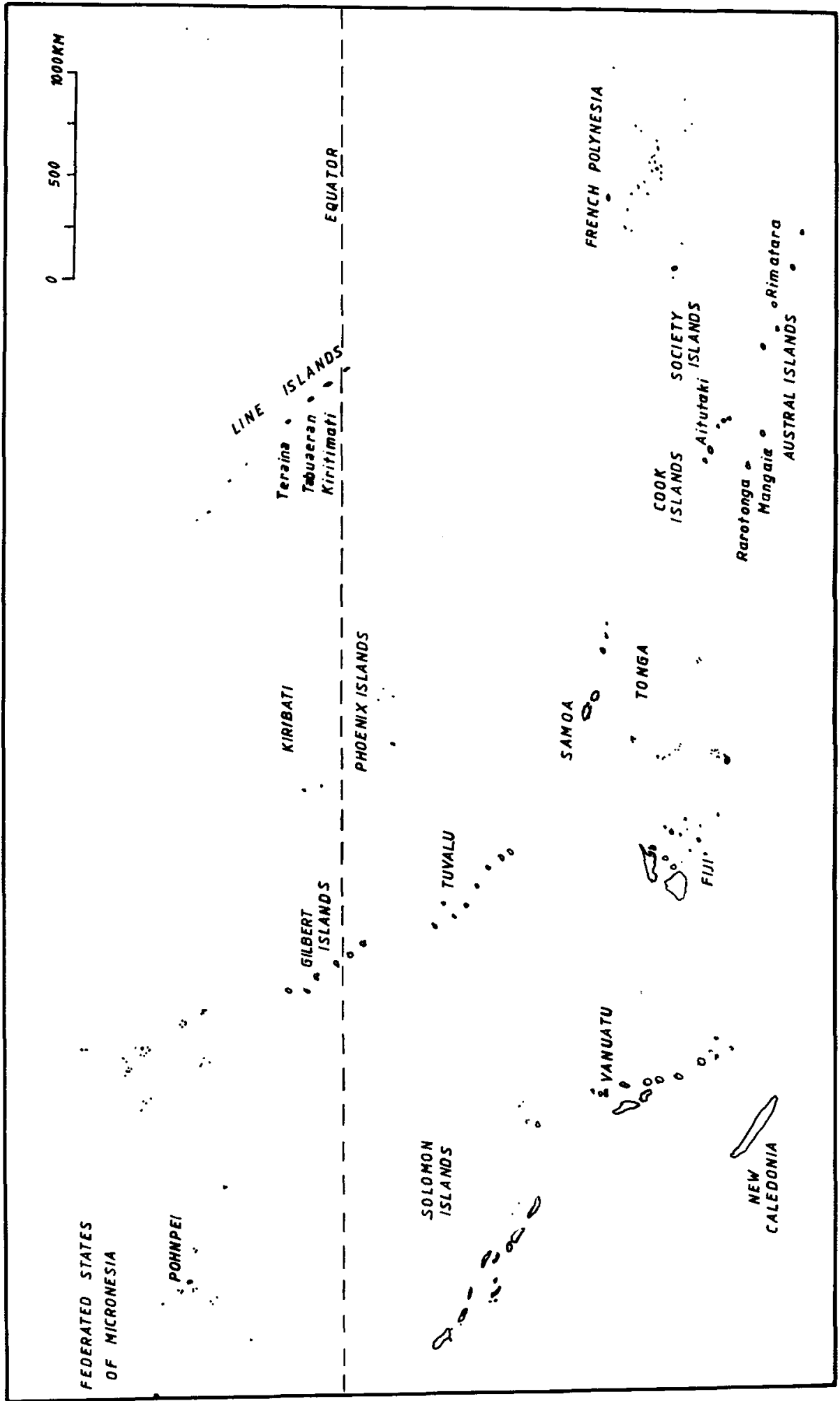

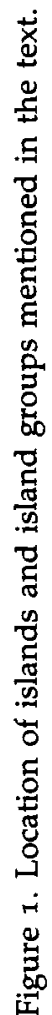


Elsewhere in the Pacific there is documented evidence of trade in live parrots and lorikeets at the time of first European contact, particularly in Fiji, Tonga and Samoa, where the Masked and Crimson Shining-parrots Prosopeia tabuensis and $P$. splendens and the Collared Lory Phygis solitarius were involved (Watling 1979, 1982). Geraghty (in press $a, b$ ) argues, mainly from oral tradition and linguistic evidence, that the trade is ancient, extending back to the earliest occupation of Polynesia, and that it was at least partly responsible for Polynesians undertaking return voyages over enormous distances to Vanuatu, Kiribati and Pohnpei. Extensive Polynesian ruins on Malden Island in the central Line Islands bear a striking resemblance to remains on Raivavae in the Austral Islands, further evidence of an ancient (pre-European contact) link between the Austral and Line Islands (M. C. Garnett in litt.).

The current Kiribati name for the lorikeet is "Kura" which is clearly a Polynesian "loan word". Perhaps not coincidentally, "Kura" is also the name for the red-feathered bird known from oral tradition in the southern Cook Islands (Savage 1962, Te Rangi Hiroa 1944) and believed from fossil evidence to be Vini kuhlii (Steadman 1985, 1991). The feathers of the Kura were much prized in the Cook Islands for personal adornment and ceremonial head-dresses (McCormack and Künzle 1993). Excessive exploitation for its red feathers would appear to be the most plausible reason for the loss of Vini kuhlii from the southern Cook Islands.

On Kiritimati Kuhl's Lorikeet has been liberated several times in the relatively recent past. Six birds were introduced in 1957, an introduction which is believed to have failed although three were still present in 1959 (Bakus 1967, Pratt et al. 1987). Several were introduced in the early 1960 s and more than one were free-flying in 1982 (Garnett 1983). More recently, three were liberated in 1991 (J. Bryden verbally 1993) and at least two still survive (K. Teeb'aki, T. Beai and J. Bryden verbally 1993).

Bruner (1972) reported that on Rimatara the lorikeets show a preference for dense, wet rainforests in the vicinity of coconut groves, but McCormack and Künzle (1993) found them to be less abundant in native makatea forest areas than in coconut plantation, horticultural woodland and Paraserianthes falcataria plantations. On Teraina and Tabuaeran, which have a long history as coconut islands, there is almost no native forest remaining and so the birds are effectively confined to coconut plantation.

The presence of ship rats Rattus rattus, and to a lesser extent house rats $R$. norvegicus, is regarded as a serious threat to populations of all small lorikeets on Pacific islands, such that nest predation by ship rats will ultimately lead to the extinction of lorikeets on these islands (Rinke 1985, 1986, Seitre and Seitre 1991, 1992, Lambert et al. 1992).

\section{Conservation status}

\section{Rimatara (Austral Islands, French Polynesia)}

Two recent observations indicate that Kuhl's Lorikeet is not under immediate threat on Rimatara. In 1990 Seitre and Seitre (1991, 1992, in litt. 1993) found it to be common, although local people reported that numbers had declined. 
Corroboration of its status lies in the report that lorikeets were said by Holyoak and Thibault (1984) to be very common there in 1974; these authors did not, however, visit the island themselves.

Following a week-long survey in 1992, McCormack and Künzle (1993) concluded that there were about 900 lorikeets on Rimatara, with a possibility of up to 1,500 . They regarded it as "common to very common" in areas of coconut plantation, horticultural woodland and Paraserianthes falcataria forests, which cover about half of the $18 \mathrm{~km}^{2}$ island.

Seitre and Seitre (1992, in litt. 1993) were the first to report the occurrence of the common rat $R$. norvegicus on Rimatara, and they trapped it there; this was confirmed by McCormack and Künzle (1993). Although this species is believed to be less destructive to small lorikeets than the ship rat (which has not been trapped there), it nonetheless poses a threat to the remaining population of $V$. kuhlii on Rimatara, and it remains to be seen if the Rimatara population has any in situ conservation potential without intervention.

\section{Kiritimati (Northern.Line Islands, Kiribati)}

Kiritimati, with an area of $363 \mathrm{~km}^{2}$, is over to times the area of Tabuaeran and 20 times that of Rimatara and Teraina. Although ship rats are not established on Kiritimati (Clark 1991, K. Teeba'aki verbally 1993), and despite the presence of a large area of coconuts (over $50 \mathrm{~km}^{2}$ ), the island's arid and unpredictable climate (average rainfall c. $700 \mathrm{~mm}$ per year but with periodic extremely severe droughts) is probably responsible for the inability of Kuhl's Lorikeets to establish themselves successfully.

The Kiribati government is intending to pursue rapid development on Kiritimati (AGRICO 1993), which may entail a considerable increase in the human population and sooner or later the construction of a jetty. It can be assumed that the latter will inevitably lead to the introduction of the ship rat given the resources available to wildlife management in Kiribati. In consequence, even if the current constraints for the lorikeets can be identified and overcome, the potential of any future conservation of Kuhl's Lorikeet in the wild on Kiritimati must be regarded as poor.

\section{Tabuaeran (Northern Line Islands, Kiribati)}

In 1963 Bakus (1967) considered the lorikeet to be "common to abundant" on Tabuaeran and made no mention of any distributional restrictions. This is hard to reconcile with Perry (1980), who described the population in the late 1970 s as "very much smaller" than the several hundred pairs on Teraina, or with Garnett (1983), who estimated a population of about 200. Both Perry and Garnett noted the restriction of the population to a single islet. More recently Pratt $e t$ al. (1987) describe Kuhl's Lorikeet as "quite common" on Tabuaeran, while Lambert et al. (1992) report a population of "a few hundred individuals"; neither reports provide a source of information.

In February 1993, following a 3-day survey, I estimated the population to be much smaller, perhaps fewer than 5o, and restricted to one location, the Betani area on the north-western islet of the atoll. No lorikeets were observed or 
reported from the two other main islets. Garnett (1983) reported lorikeets to be most common a decade earlier on this same islet, while Perry (1980) had been informed that the birds were confined to it.

The ship rat was first noted on Tabuaeran in the early 1920s (Herms 1926) and again in 1937 (Smith 1969), and is probably responsible for the extinction of the endemic race of the Bokikokiko Acrocephalus aequinoctialis pistor sometime between 1924 and 1963, and for the apparent decline of the population of Kuhl's Lorikeets. During the operation of Tabuaeran as a copra plantation, rat damage to coconuts was not regarded as a major problem (J. Bryden, former plantation manager, verbally 1993), but since the abandonment of plantation operations in 1983 the coconut stands have not been cleared or thinned, providing better habitat for rats, and today rat damage is a serious problem for the subsistence farmers (pers. obs.).

It would appear that the lorikeets have managed to survive for over 70 years in the presence of the ship rat, but have been confined to one location for the last 15 years at least, and perhaps for much longer. Lambert et al. (1992) were unaware of the presence of ship rats on Tabuaeran.

In view of the general belief that the introduction of ship rats will ultimately cause the extinction of Vini lorikeets on small islands (Rinke 1985, 1986, Lambert et al. 1992, Seitre and Seitre 1992), it is important to know how the Tabuaeran population has managed to survive for at least 70 years in their presence and the possible significance of its restriction to one location for such a long time. Indeed, it is possible that the ship rat has been on Tabuaeran even longer, because Kirby (1925) noted that the lorikeet "is far less numerous than it once was", indicating that a population decline had already commenced. However, in apparent contradiction and as noted above, Bakus (1967) described the lorikeet as common to abundant at the time of his visit in 1963 .

Following observations in French Polynesia, Seitre and Seitre (1992) speculated that the restriction of the lorikeet to one of Tabuaeran's islets was due to the probable absence there of humans and other exotic mammals. Although ship rats were definitely present on the north-western islet in 1979/ 1980 (M. C. Garnett in litt.) and the occurrence of rat damage (pers. obs. 1993) confirms their presence there today, it is possible that they colonized the islet relatively recently, which could account for the existence of the remnant lorikeet population. However, the islet in question is the location of Cable and Wireless's central Pacific telephone cable relay station, which was permanently manned from its establishment in 1902 until 1964, and it seems likely that the construction of the relay station and regular subsequent visits for provisioning and equipment repair were the means of colonization of Tabuaeran by the ship rat.

On Tabuaeran I was informed that a lorikeet nest had been found in the rotten trunk of a Pandanus tree. It would be interesting to know if the population has survived because it has a nesting site away from the "normal" coconut habitat of the ship rat. This should be investigated as it has important implications for the future conservation of this and other Vini lorikeets. Small areas of Pandanus-dominated woodland are still present on Tabuaeran in low-lying, poorly drained sites, but the Pandanus is likely to be increasingly felled by new settlers for use in house construction. 


\section{Teraina (Northern Line Islands, Kiribati)}

Teraina is a most strange, but not unique, island, being a coral atoll with the central depression enclosed and containing freshwater wetland habitats (Figure 2). On Teraina these consist of a 280 ha lake and two peat bogs of about 180 ha surrounded by approximately $11.5 \mathrm{~km}^{2}$ of plantation, predominantly coconuts. The island receives a high annual rainfall averaging approximately $2,900 \mathrm{~mm}$.

Perry (1980) described the lorikeet population as stable at "several hundred pairs". Garnett (1983) estimated a population of at least 1,000 birds. Pratt et al. (1987) describes Kuhl's Lorikeet as "quite common" on Teraina, while Lambert et al. (1992) report a population of "a few hundred individuals" but without a source of information.

In February 1993, on the basis of transect counts around the entire island, over a three-day period, I calculated a population of between 1,000 and 1,600 birds. Teraina is elliptical in shape, with a coastal and an interior road, and with essentially only two lorikeet habitats: gardens, and slightly overgrown coconut plantations. Using these roads I covered the island twice on successive mornings, and covered half the island on the third. I divided encounters with lorikeets into "seen" (flock-size recorded) and "heard" (no observation made), and on the basis of the mean flock-size in "seen" encounters I multiplied the "heard" encounters accordingly. The main uncertainties were over attributing heard records to within or outside the transect width, and over possible double counting. The upper and lower limits $(1,600$ and 1,000$)$ are extrapolations from the maximum and minimum densities obtained in the three counting periods.

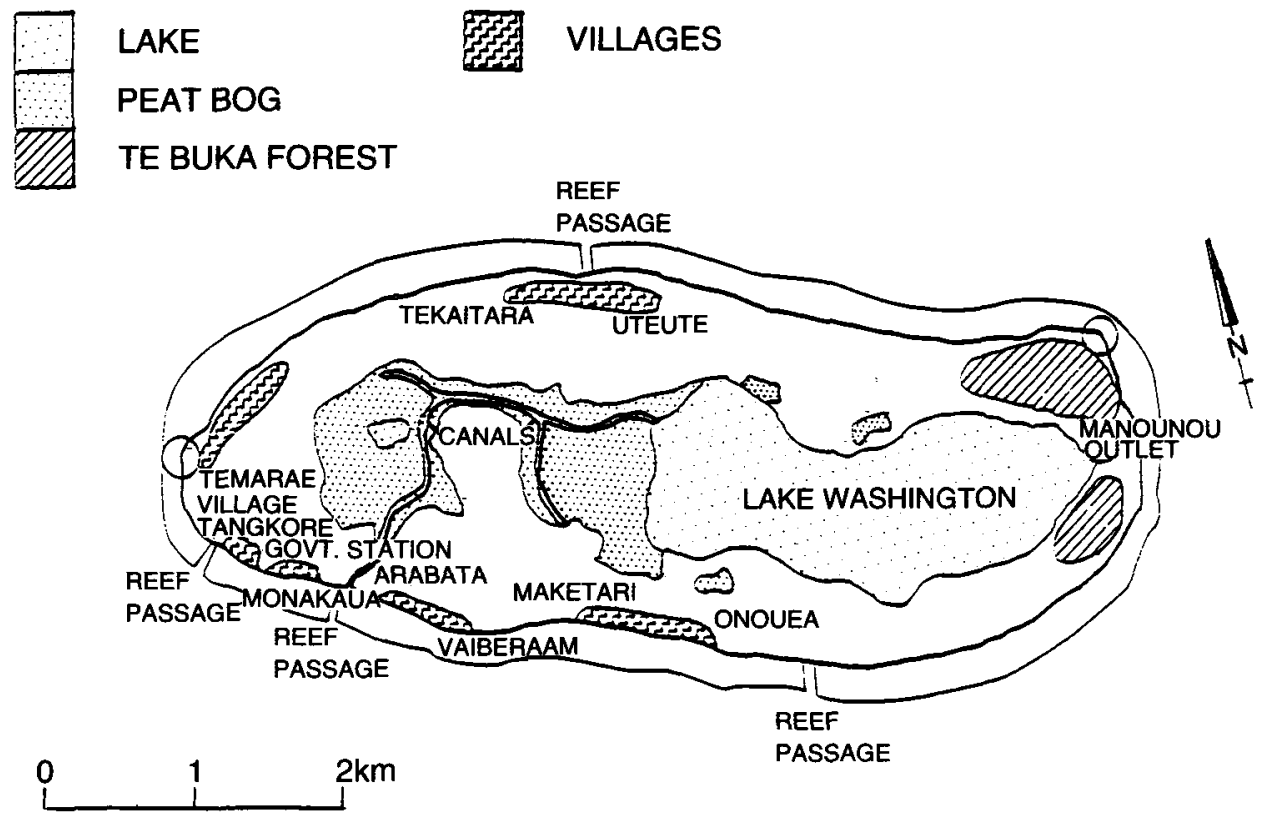

Figure 2. Teraina (Washington Island). Te Buka forests are areas of unmanaged forest dominated by Pisonia grandis. A detailed vegetation map of Teraina may be found in Wester et al. (1992). 
Given the assumptions which were necessarily made and the brevity of the counting period, Garnett's (1983) figure of 1,000 should be confirmed as a good conservative estimate of the population of Kuhl's Lorikeets on Teraina.

The ship rat was recorded as present on Teraina in 1924 by Herms (1926), but this clearly needs confirmation. Herms was only on the island for three days and was injured on landing, making his study rather difficult (Herms 1926). I did not observe any rat damage to coconuts (an indication of ship rats) and islanders reported that it was not a problem. Polynesian rats $R$. exulans are abundant (M. C. Garnett in litt.).

In the past, Teraina was visited by ships only once or twice a year; it has a very poor anchorage and a notoriously bad landing. The current human population is about 1,000 , but there are moves to establish up to 1,000 more subsistence settlers on the island. While there is little likelihood of a jetty ever being built for both engineering and economic reasons - there will be a marked increase in the number of ships visiting the island and possibilities for the introduction of ship or common rats are thus increased.

Nevertheless, Teraina's population of Kuhl's Lorikeets would seem to be the world's largest and most secure, with good in situ conservation potential and without any need for intervention. This is presuming, of course, that Herms (1926) was incorrect and that the ship rat is not present. Confirmation of the absence of the ship rat is clearly a priority, although if it is in fact present on Teraina then the general belief that South Pacific lorikeets and ship rats cannot coexist needs to be re-examined.

Teraina's flora includes only 25 indigenous species, but a further 66 cultivated or adventive species currently occur on the island (Wester 1985). Pollen analysis of peat-core samples (Wester et al. 1992) indicates that coconuts Cocos nucifera on Teraina appear to pre-date European contact and either arrived there naturally or with the Polynesian voyagers who brought the lorikeets. Today the forest is completely dominated by mixed-age stands of coconuts, which have been scarcely managed in the past and now cover some 847 ha. A few small, isolated stands of Pisonia grandis have survived, and the trees grow to a remarkable height, approaching $30 \mathrm{~m}$ with a girth at breast height of up to $13 \mathrm{~m}$ (M. C. Garnett in litt.). Around the peat bog and in the wetter areas Pandanus spp. invade the coconut stands. Teraina's maximum elevation of less than $4 \mathrm{~m}$ is at the beach crest, which supports a distinct vegetation. This coastal fringe, generally not more than $10 \mathrm{~m}$ wide but sometimes extending $100 \mathrm{~m}$ inland, is dominated by Messerschmidia argentea with Scaevola taccada and less commonly Cordia subcordata.

The lorikeets use all the terrestrial habitats on Teraina and are commonly seen flying over villages and visiting trees in village gardens. The only feeding observations made were on the flowers of coconut, Terminalia catappa and those of the only Premna obtusifolia on the island. A lorikeet was also observed stealing coconut flower "toddy" as it drained into its coconut shell container.

\section{Conservation management on Teraina and elsewhere in Kiribati}

Kiribati is not a signatory to any international or regional environmental or conservation convention. Nonetheless, it has well-developed wildlife 
legislation. Kuhl's Lorikeet is a "fully protected" bird under the Wildlife Conservation Ordinance 1975 through the "Birds Fully Protected Throughout the Gilbert Islands Order 1979". The ordinance prohibits the hunting, killing or capture (Section 5) and possession (Section 9) of fully protected birds.

Currently a Wildlife Unit of three men is stationed on Kiritimati. Unfortunately, the Unit is poorly resourced, facing major transport difficulties and able to make only very rare visits to Teraina and Tabuaeran. Until my visit, the Unit was unaware of the international significance of Teraina's population of Kuhl's Lorikeet, but the warden is fully conversant with the legislation and the Unit is effective in applying it to the limit of its own restricted resources and those of the police, judicial and administrative assistance which is currently available to them on Kiritimati.

Kuhl's Lorikeets are reported to be readily caught by Teraina's villagers but I saw none as pets during my visit. Villagers and island officials were aware that all birds are protected, but did not realize that capture and possession are also prohibited under Kiribati's 1975 Wildlife Conservation Ordinance. Currently there is need for greater awareness and enforcement of the legislation, and in the future Kiribati will need to be wary of trade in Kuhl's Lorikeets and ill-conceived captive-breeding schemes.

\section{Acknowledgements}

I am very grateful to Dr G. S. Sandhu of the Kiribati Department of Agriculture for providing me with the reference of $F$. J. Smith concerning the ship rat on Tabuaeran, and to Alison Stattersfield of BirdLife International for a copy of M. C. Garnett's 1983 report. Chief Warden Katino Teeb'aki, Wildlife Conservation Unit, Kiritimati, shared his knowledge and provided much help and assistance on Kiritimati.

\section{References}

AGRICO (1993) Northern Line Islands Integrated Development Plan for the Republic of Kiribati. Asian Development Bank TA No. 1630-KIR. Auckland, New Zealand: AGRICO of New Zealand.

Bakus, G. J. (1967) Changes in the avifauna of Fanning Island, central Pacific, between 1924 and 1963. Condor 69: 207-209.

Bruner, P. L. (1972) Birds of French Polynesia. Honolulu: Bernice P. Bishop Museum.

Clark, J. (1991) Observations on the birds and mammals of Kiritimati with recommendations on the protection of the seabird nesting colonies. Unpublished report to New Zealand Ministry of External Relations and Trade.

Fanning, E. (1989) Voyages and discoveries in the South Seas, 1792-1832. New York: Dover (facsimile reproduction of 1924 publication).

Forshaw, J. M. (1989) Parrots of the world. Third (revised) edition. London: Blandford Press.

Garnett, M. C. (1983) A management plan for nature conservation in the Line and Phoenix Islands. Unpublished report, Government of the Republic of Kiribati.

Geraghty, P. (in press a) Pulotu, Polynesian Homeland. J. Polynesian Soc. 102 (4).

Geraghty, P. (in press b) Linguistic evidence for the Tongan Empire. Paper presented at Comparative Austronesian Project Symposium on "Contact-induced language 
change", 26 August-1 September 1989, Dept of Linguistics, Research School of Pacific Studies, ANU Canberra.

Herms, W. B. (1926) Diocalandra taitensis and other coconut pests of Fanning and Washington Islands. Philippines J. Sci. 30: 243-274.

Holyoak, D. T. and Thibault, J.-C. (1984) Contribution à l'étude des oiseaux de Polynésie orientale. Mém. Mus. Natn. Hist. Nat. Ser. A, Zool. 127: 1-209.

Kirby, H. (1925) The birds of Fanning Island. Condor 27: 185-196.

Lambert, F., Wirth, R., Seal, U. S., Thomsen, J. B. and Ellis-Joseph, S. (1992) Parrots: an action plan for their conservation and management (draft). Cambridge, U.K.: International Council for Bird Preservation and International Union for Conservation of Nature and Natural Resources/SSC Captive Breeding Specialist Group.

McCormack, G. and Künzle, J. (1993) In search of two plants and a bird lost from the Cook Islands. The Cook Islands Natural Heritage Project Expedition on the Yacht Ardevora to the Austral Islands (15 July-15 August 1992). Unpublished report.

Perry, R. (1980) Wildlife conservation in the Line Islands, Republic of Kiribati (formerly Gilbert Islands). Envir. Conserv. 7: 311-318.

Pratt, H. D., Bruner, P. L. and Berret D. G. (1987) A field guide to the birds of Hawaii and the tropical Pacific. New Jersey: Princeton University Press.

Rinke, D. (1985) Zur Biologie des Blaukappchens (Vini australis), mit Bemerkungen zum Status der Maidloris (Gattung Vini). Trochilus 6: 21-40.

Rinke, D. (1986) The status of wildlife in Tonga. Oryx 20: 146-151.

Savage, S. (1962) A dictionary of the Maori language of Rarotonga. Wellington, New Zealand: Government Printer.

Seitre, R. and Seitre, J. (1991) Causes de disparition des oiseaux terrestres de Polynésie Française. Apia, Western Samoa: South Pacific Regional Environment Programme (SPREP Occas. Pap. 8).

Seitre, R. and Seitre, J. (1992) Causes of land-bird extinctions in French Polynesia. Oryx 26: 215-222.

Smith, F. J. (1969) Rodent research in the Gilbert and Ellice Islands Colony, 1967-69 with control recommendations. Unpublished report, Government of the Republic of Kiribati.

Steadman, D. W. (1985) Fossil birds from Mangaia, Cook Islands. Bull. Brit. Orn. Club 105: 58-66.

Steadman, D. W. (1991) Extinct and extirpated birds from Aitutaki and Atiu, Southern Cook Islands. Pacific Sci. 45: 325-347.

Te Rangi Hiroa (1944) Arts and crafts of the Cook Islands. Bernice P. Bishop Mus. Bull. 179: 1-533.

Watling, D. (1979) A collection of Fijian and Tongan landbirds. Bull. Brit. Orn. Club 98: 95-98.

Watling, D. (1982) Birds of Fiji, Tonga and Samoa. Wellington, New Zealand: Millwood Press.

Wester, L. (1985) Checklist of the vascular plants of the Northern Line Islands. Atoll Res. Bull. 287: 1-38.

Wester, L., Juvik, J. O. and Holthus, P. (1992) Vegetation history of Washington Island (Teraina), Northern Line Islands. Atoll Res. Bull. 358: 1-50.

DICK WATLING

Box 2041, Government Buildings, Suva, Fiji 